\title{
Scriber Device
}

National Cancer Institute

\section{Source}

National Cancer Institute. Scriber Device. NCI Thesaurus. Code C50162.

A pointed device designed to etch a mark on an object. 